Article

\title{
Transitions and Conflicts: Reexamining Impacts of Migration on Young Women's Status and Gender Practice in Rural Shanxi
}

\author{
Lichao Yang ${ }^{1}$ and Xiaodong Ren ${ }^{2, *}$ \\ ${ }^{1}$ School of Social Development and Public Policy, Beijing Normal University, 100875 Beijing, China; \\ E-Mail: yanglichao@bnu.edu.cn \\ 2 National Engineering and Technological Research Center of Karst Rocky Desertification Prevention and Control, Guizhou \\ Normal University, 550001 Guiyang, China; E-Mail: renxiaodong@hotmail.com \\ * Corresponding author
}

Submitted: 17 November 2019 | Accepted: 10 February 2020 | Published: 28 April 2020

\begin{abstract}
This article explores impacts of migration on young women's status and gender practice in rural northern China. Based on ethnographic fieldwork in a village in Shanxi Province, it suggests that rural-urban migration has served partially to reconstruct the traditional gender-based roles and norms in migration families. This reconstructive force arises mainly from the changes of the patrilocal residence pattern and rural women's acquisition of subjectivity during the course of migration. However, after migrant women return to their home villages, they usually reassume their roles as care providers and homemakers, which is vividly expressed by a phrase referring to one's wife as 'the person inside my home' (wo jiali de). Meanwhile, although migrant women's capacity and confidence have greatly increased consequent upon working out of the countryside, their participation in village governance and in the public sphere has been decreasing. Further examination suggests that the reinforcement of gender inequality and the transformation of gender relations result from the continuous interplay of local power relations, market dominance, and unchallenged patrilocal institutions. Through adopting a life course perspective, it challenges too strict a differentiation between migrant and left behind women in existing literature.
\end{abstract}

\section{Keywords}

gender relations; migration; patriarchy; rural Chinese women

Issue

This article is part of the issue "Left Behind? Women's Status in Contemporary China" edited by Robert Walker (Beijing Normal University, China) and Jane Millar (University of Bath, UK).

(C) 2020 by the authors; licensee Cogitatio (Lisbon, Portugal). This article is licensed under a Creative Commons Attribution 4.0 International License (CC BY).

\section{Introduction}

During the last three decades, continuous large-scale rural-urban migration has brought about a separation of families with 169 million people leaving their villages, $68 \%$ of them men (National Bureau of Statistics of the People's Republic of China, 2016). For most of the migrant workforce, migration means dispersing the family. According to estimates by Zhang (2006), 47 million families have been separated as a result of the husband leaving in search of work and the wife staying behind. Even so, more than 50 million rural women work as mi- grant workers in urban areas, which accounts for $40 \%$ of the migrant population (National Bureau of Statistics of the People's Republic of China, 2009). Most female migrant workers are young women who take up lowskilled, gender-specific jobs in light manufacturing factories, restaurants and hotels, or as domestic service providers (Jacka, 2006; Zhang, 2013). However, research shows that the opportunities for upward social mobility of young migrant women are very limited (Zhang, 2006). The majority chooses to marry their migrant peers whom they have met at work and return to their husbands' villages for child rearing, and many of these fe- 
male returnees become left-behind women while their husbands continue to work in the cities. Nevertheless, it is important to ask: Why is it usually the wife rather than the husband who stays behind? The typical response is economic rationality having taken into consideration the different market returns for men and women and differential costs of living. However, the reality is that it is often possible for women to get jobs more easily than men and to earn more money.

This conundrum has recently been expanded through two bodies of feminist scholarship: The first draws on traditional gender norms and practices. It shows that the decision to have the wife stay behind to cultivate the land and take care of the home is often dictated by traditional sex role conventions: 'The man dominates outside and the woman dominates inside' (nanzhuwai, nüzhunei; see, e.g., Chen, 2004; Jacka, 2008; Pu \& Chen, 2018; Shek, 2006). It also implies that marriage has completely different meanings for a man and a woman: It is considered right and proper for a married woman to take care of the house and for a married man to go out to earn a living. The second body of feminist scholarship draws on migrant women's experiences of hardship in cities. A national survey indicates that female migrant workers are paid only $80 \%$ of their male colleagues in the same work position. $60 \%$ of female migrants work without employment contracts, $76 \%$ of them do not have medical insurance, $85 \%$ cannot access pension schemes, and $92 \%$ are not covered by unemployment insurance (Chinese Women and Children's Rights Coordination Group, 2007). During the 2010s, the proportion of women migrants who were married increased markedly but, on average, they earned $15.6 \%$ less than other women (An, Broadbent, \& Yuan, 2018). In addition to hardships at work, both single and married migrant women receive less social support from home and social networks and consequently are in worse situations compared to their male counterparts (Li, Yang, Yue, \& Jin, 2007; Liu, Yin, Huang, Lin, \& Zhang, 2010). Some scholars therefore argue that rural migrant women are the most oppressed social groups in contemporary China (Au \& Nan, 2007; Jacka, 2006; Murphy, 2002; Zhang, 2013). For all the reasons explained, unless both husbands and wives return to home villages, husbands taking migrant jobs while wives staying behind at home become dominant gender division of labor in rural households.

Studies have revealed that left-behind women shoulder heavy workloads (e.g., Jacka, 2012) but equally that some of them have attained increasing authority and decision-making power (e.g., Judd, 1994, pp. 189-191). However, the label 'left behind women' confounds different kinds of migration trajectory and experience which can be understood more clearly through adopting a life course perspective as below. The impact of different migration experiences on the status of young women and on their gendered power relations within households and the wider community is explored through ethnographic research conducted in Shanxi.

\section{Review of Rural Women's Status and Gender Relations}

Economic reforms have brought new forms of gender inequality and discrimination against rural women. In the reform era since the opening up of the Chinese economy in the 1980s, rural women's political participation has declined and rural girls have continued to enjoy fewer educational opportunities than boys (Zeng, Pang, Zhang, Medina, \& Rozelle, 2014). Before the reforms, rural women were bound to the land. The household registration system restricted their mobility, except through marriage and a few other means (Xiang, 2015). China's moves toward a market economy have loosened the hold of the household registration system and encouraged young rural women and men to work away from home (Yan, 2003). Millions of young, rural women have migrated to cities and more economically developed regions, working as waitresses, domestic workers, and factory production line workers, or transporting and selling goods from one place to another. They have undertaken the dirtiest work with the lowest wages and been marginalized by urban residents because of their rural identity. As Zhang (2014) has indicated, after more than 25 years of economic reform, a small number of rural migrant women have settled in cities and become integrated into urban life, but the majority of others are still working at the bottom of the urban social hierarchy.

At present, young men and women have little choice but to separate from their families and migrate in search of paid work because of low incomes to be derived from agricultural activities and the increasing costs of education, health service, and marriage. However, land is still regarded as peasants' final guarantee, given the fact that they have no pension or easily accessible health insurance. Therefore, to 'guard the land' (shou tu) is as important as to 'leave the land' (li xiang) for paid work (Li, 2016). In rural areas, therefore, with most men and young single women away working, middle-aged women have increasingly been taking on the heavy work burden and responsibility for farming. More than $60 \%$ of farm work is currently being undertaken by middle-aged and older women (Zhang, 2014), work that is in addition to reproductive activities which sustains the development of the Chinese rural sector while freeing male labor for urban development. Almost all the women will be married, frequently with their own husbands working away from home. Importantly though, increasing numbers of these women will themselves have experienced migrant work, returning from the city when childcare responsibilities can no longer be discharged by other relatives. Left-behind women have often been categorized by feminist scholars as a marginalized group, distinct from migrant women on account to the multiple practical challenges they face as a consequence of families being split (Chen \& He, 2015; Smyth, Swendener, \& Kazyak, 2018; Zhu, 2018). However, it is important to recognize that many migrant women become left behind women, left 
behind in villages that were not their own due to adherence to the social norm of patrilocal residence.

The unprecedentedly large-scale rural-urban migration since the 1990s has not only broken down the geographical boundaries of everyday life (Liu, Lin, Zhang, \& Li, 2019), but also dissembled the older, locally-based organizations and the relationships based on them (Chen, 2019; Du, 2019). For most of the migrant workforce, migration means geographically separating family members. In the course of this process, a change in family dynamics has inevitably occurred. Migration has destroyed the basic family form associated with traditional agricultural society in which the whole clan lived together, thereby sundering the kinship networks established on this basis. De-localization resulting from population movement has eroded and undermined the patriarchal family system, with its high degree of overlap between kin-based and place-based ties (Jin, 2010; Sargeson, 2018). Nevertheless, despite the spatial separation, family members manage to maintain marital ties and basic family functions. They have no choice but to construct a flexible mode of production and life that spans urban and rural areas (Jin, 2009).

At the individual level, continuous large-scale migration has brought about atomization and individualization. Even a temporary move away from the old family and community order can free individuals from the control of the male head of the household and the coercive norms of traditional customs. With their adult children away from home, parents cannot organize their offspring's lives nor make decisions for them. Delocalization resulting from migration has therefore reduced the ability of the older generation to control individual family members, especially young people. Moreover, the huge gap between income obtainable from temporary jobs in the cities and that from farming has shifted economic power within the family from the older to the younger generation. This redistribution of intergenerational power has been accelerated by the more individualistic value orientation engendered among young migrant workers who have not only shown their superiority within the economic sphere field but also in other areas of social activity (Jin, 2010).

Migration, therefore, has shattered pre-existing hierarchies and structures of family life, reshaped generational and gender relationships, and promoted the growth of individualization among rural-urban migrants. In considering its impact of women, the experiences of migrant women have tended to be positively contrasted with those of women left behind. But the reality is that these two groups are increasingly comprised of the same women as family responsibilities and reverse migration following the post global financial crisis has brought large numbers of both women and men migrant workers back to rural villages and nearby towns. This realization provokes several questions that are the focus of the ethnographic fieldwork in northern Shanxi reported below. What has happened to individualized women migrants when they are re-embedded in the family and family relations through marriage? Have they gained more power in everyday gender practice at family and community levels than older generations? What are the impacts of the returned migrants on gender dynamics?

\section{Research Methods}

The article draws on findings from qualitative fieldwork in Maple Administrative Village comprising of five natural villages (or village groups) in Wood County, itself nested within Forest Township in northern Shanxi Province: Pseudonyms for all informants and the Village are used to ensure anonymity. Situated on the northern slopes of the Taihang Mountains, opposite a rather broad and fertile plain, forests, streams, grasslands, and farming lands belonging to the Village have been contracted to individual households since the mid-1980s. The population has nevertheless declined from about 2100 in 2000 to some 1200 in 2017. A little over a third of married women are non-local, having met their husbands during their time as migrant workers, moving to their husbands' village according to patrilocal norms.

The ethnographic fieldwork took place between 2013 and 2017 and included participant observation in the Village and 200 interviews with villagers living in all 150 households containing women aged 20-45, hereafter referred to as 'young women.' All told, 200 indepth interviews were conducted with 26 unmarried and 124 married young women and their family members including 30 young men and 20 older villagers. All the transcripts fieldnotes were open-coded by a team of 20 and subjected to a thematic analysis coding most aspects of lifestyle. Themes appertaining to status and gender relations are reported below, illustrated through the words and experiences of eight young women and their families.

The remainder of the article draws on the ethnographic research findings to explore the transformation of young women's role and gender practice against a background of rural-urban migration and return migration. It suggests that women's experience of migrant work has promoted cross-regional marriages, which weakens the bond between individual women and their natal families as well as breaks local customs and norms both in their natal and marriage villages. After returning to their husbands' village, young women can escape cultural practices which infringe on their rights and beliefs that they picked up from urban lives. Meanwhile, the practice of patrilocal arrangement makes these women a vulnerable target for exploitation, abuse, and discrimination. As both outsider and 'the person inside my home,' women are political under-represented in community governance. In most cases, the rights and freedom of women who have migrated are infringed after they return to their home villages. The final section draws a brief conclusion. 


\section{Transformation of Young Women's Role and Gender Practice in Maple Village}

In Maple Village, the majority of younger villagers had experience of migrating for work to nearby cities, counties, and townships in non-agricultural sectors. Most men had been engaged in construction work and women had worked in service sector. Among all married interviewees, 96 of 124 women (77\%) had themselves experienced working away from the Village; 71 of the 96 women $(74 \%)$ got to know their husbands during their time as migrant workers; and 34 of the 71 (48\%) did not live in Maple Village before they married although the majority came from other places within Shanxi or other nearby provinces (Table 1). Only two women are from other remote provinces; one is from Hubei, the other one is from Guangxi. Most daughters-in-laws who originally came from remote regions were unwilling to live in Maple Village if their husbands worked away from home. Instead, they sought to stay in Maple Village for only one to three years as necessitated by pregnancy and childrearing, then leaving their children with their parents-inlaw to join their husbands in migrant cities to avoid being left behind in the Village. Nevertheless, the proportion of young women who moved to Maple Village on marriage increased dramatically between 1990 and 2016.

Among the local women who had migrant experiences, $90 \%$ had worked within Shanxi Province while $73 \%$ had worked elsewhere (Table 2). Near half of women who had worked outside Shanxi Province married and moved out of Maple Village to join in their husbands. Among the 96 migrant women engaged in this research, 67 had experience of working both within and outside Shanxi Province.

\section{Delocalization, Individualization, and Breaking Away from the Old Order}

Traditionally, the daily life of Chinese peasants was highly localized with families living in the same locality generation after generation, but women's cross-regional movement has resulted in the dissolution of regional identity and the sense of local belonging, a process termed 'delocalization.'

The impact of delocalization on women's roles and status can be exemplified by Chen Juan's case, albeit she, as a distant migrant, is unusual in remaining in Maple Village while her husband continued with migrant work. Chen Juan is a 34-year-old woman with two sons. In the early 2000s, Chen left her natal home in Hubei Province and worked as a waitress in a small restaurant in Beijing. She fell in love with $\mathrm{Li} \mathrm{Yi,} \mathrm{a} \mathrm{coworker} \mathrm{who} \mathrm{came} \mathrm{from}$ Maple Village. Despite objections by her parents mainly because of the long distance between the couple's hometowns, Chen Juan married Li Yi in 2004 and they continued working as migrants in Beijing. In 2005, Chen Juan went back to Maple Village after she became pregnant and thereafter lived in Maple Village while her husband worked away from home. When talking about her localization in Maple Village, Chen Juan said:

Table 1. Married young women's premarital residence in Maple Village in 1990 and 2016.

\begin{tabular}{lcc}
\hline Married Young women's premarital residence & Percentage in 1990 (\%) & Percentage in 2016 (\%) \\
\hline Local residence & 92 & 63 \\
Residence in Maple Village & 45 & 15 \\
$\quad$ Residence in T County or nearby counties & 47 & 48 \\
Nonlocal residence & 8 & 37 \\
Residence in remote parts of Shanxi Province & 2 & 5 \\
Residence in nearby provinces & 0 & 23 \\
Residence in other remote provinces & 6 & 9
\end{tabular}

Notes: There were 753 married women documented in 1990 and 351 in 2016. Data in 1990 was from Maple Village Demographic Record in 1990.

Table 2. Young women's experience as migrant workers in Maple Village, 2016.

\begin{tabular}{lc}
\hline Young women's experience as migrant workers & Percentage (\%) \\
\hline Work within Shanxi Province & 90 \\
Work at T County or nearby D City & 76 \\
Work at the capital city of the Province & 8 \\
Work at the other places of the Province & 63 \\
Work outside Shanxi Province & 15 \\
Work in first-tier/coastal cities & 42 \\
Work at other nearby provinces & 16 \\
Work in remote provinces & 16
\end{tabular}

Notes: These two groups overlapped. Only premarital residents of Maple Village, 100 young women, were recorded in this table. Data retrieved from Village documents. 
Local customs in Maple Village is so different from us [in my hometown in Hubei]....To celebrate Chinese New Year and other major festivals, they [people in Maple Village] kneeled and kowtowed to the older people, especially the older males of the same clan in the Village....I feel it is hard for me to kowtow to strangers. So, I never appear in these occasions, [although] I know my parents-in-law expect me to do that. But in general people are so kind and they don't blame me because they understand that I am a southerner and I am not used to do this in my natal village....But nor do I do what I did in my natal home. [For example], I never go to temples to pray which everybody does during festivals in my hometown, even my mother called and urged me to go.... I feel I am neither from Hubei nor Shanxi. Sometimes I am confused but for most of the time, I feel I am free from these customs, which is good.

Chen Juan's case illustrates how cross-regional marriage weakens the binding force of place-based traditional customs, embodying clan seniority, age, and gender together with associated normative knowledge. Therefore, delocalization will lead to a breaking away from the older order. In the course of migration, women are likely to have not only improved their marital autonomy but also acquired the consciousness and courage to contend with gender discrimination. Even a temporary and partial deviation from the older order may have a significant effect in individuals from the control of the male head of the household and the coercive norms of traditional customs. As Chen Juan further put it:

My parents-in-law were not happy when they saw my husband cleaning the kitchen after dinner. They said that 'a man should not stay in the kitchen.' I try to avoid any conflicts with them, but I still think that I cook so he ought to do the cleaning. When we worked together in the city, it was always me cooking and my husband did the cleaning, as all the other couples did in urban areas. My parents-in-law don't come to our house that often now, maybe they have realized that they cannot change our lives in our house.

As illustrated in the above quotation, couples with migration experiences typically adopted a new gendered division of labor within their household. These new arrangements freed younger generations from parental control and undermined the traditional gender norms within their extended family. This deconstructive force is mainly a product of rural women's acquisition of subjectivity during the course of migration and from the break with the old order resulting from delocalization.

Migration serves both as a process whereby the younger generation of women is stripped away from traditional customs and a process of restructuring family power relations. On one hand, the huge gap between the income obtainable from temporary jobs in the cities and subsistence income from farming has accelerated the shift of economic power within the family from the older to the younger generation. On the other, the individualistic value orientation of young migrant workers has exacerbated the decline of the older generation's familial power.

Interviews with older family members who were usually parents-in-law of married young women revealed that older generation has gradually lost their ability to control individual family members, including their daughters-in-law. For example, Zhang Li, a woman in her mid-20s who returned to Maple Village in late pregnancy in 2016, recognized parents-in-law were "not in a position to decide for them." Her mother-in-law explained that the majority of family income was generated by the younger people, therefore, she sighed:

The status of younger people, especially the daughters-in-law, is so different from us in the old times. They, rather than older people, dominate family affairs....My son has to [make money and] maintain his small family and daughter-in-law is in the position to budget expenditures.....Nowadays all money comes from young people's income from migrant work, therefore we older people have no power to command them.

New living conditions provide another important precondition for the young generation to free themselves of parental control. Alongside the general economic development in rural China, most young couples were able to afford to have their own houses detached from the elderly. Over $90 \%$ of the young women we interviewed in Maple Village did not live together with their parents-in-law.

Young married women were not alone in finding in the experience of migration the courage to challenge patriarchy; unmarried young women were able to do so too. Interviews indicated that leaving home to work serves as an important option, enabling young women to gain greater economic and marital autonomy in the future. For example, Mingjuan, a 19-year-old, stayed at home for two years after her middle school. She negotiated with her parents about going to the adjacent $D$ city for work, but as the only daughter of her parents, she was not initially allowed to leave home. Mingjuan said:

Parents encouraged my brothers to work in D city, but they didn't want me to go. Maybe they were scared of me marrying far away from home. But I need to prove my worth too.

\section{Patrilocal Residence and Women's Subordination within the Household}

Despite the reconstruction of inter-generational power relations within the extended family, field observations show that the traditional pattern of male domination 
and female subordination persists within the nuclear family, even among younger generations with experience of migration. While migration promotes a focus on individual achievement, albeit in the interests of the family, and stimulates greater gender equality within conjugal relationships because of both partners earning, the ideology of the patriarchal family continues to shape attitudes and behavior especially after returning from the city.

Within the nuclear family, even if female family members earn more than their male counterparts, the boss of a family remains the husband and the gender division of labor in these migrant families also follows the old practice: The man goes out to work while the women takes care of the house. To illustrate, Cai Ying, a woman in her early 40s, met her husband during migration work in $\mathrm{H}$ city and moved to Maple Village on pregnancy. She looked after household as well as ran a shop while her husband worked away in the construction industry as a carpenter. She complained about gender-based division of labor in her family:

Since we came back to his village, he has become increasingly unhappy to share housework at home because most other women in the village manage everything at home while husbands pick up paid jobs. He feels his face is put down on the ground if he does it....We both make money for the family. But we cannot go back to the old days when we worked away from home in $\mathrm{H}$ city and both shared the household chores.

In her husband's view, however, when asked about his wife's contribution to the family, he explained:

I bring money home every month and the shop is always there no matter who looks after it. With or without my wife, our family income is a fixed number. My life is just easier and more comfortable with her around.

As illustrated by the above quotations, it remains the prevailing view that it is appropriate for a married woman to take care of the house and for a married man to earn. This is mainly because of different social expectations for gender roles rather than the superior market returns that can sometimes be achieved by men. In the patriarchal family system, the household chores and services performed by women are unpaid and therefore not included in cost accounting. Accordingly, it is a 'natural' choice for the migrant family to use women's unpaid work to minimize the apparent costs of providing necessary care for children and elders.

Fieldwork in Maple Village shows that $80 \%$ of migrant women who return to the Village do so because of family reasons including the need for support from gaining extended family during pregnancy and child rearing. But such decisions are also driven by husbands' conscious- ness of their rural roots. As indicated in Cai Ying's case, younger women gain more power in the process of migrant working, however, the existence of patrilocal residence reinforces male dominance and unequal gender relations. Her contribution to family income was greatly undervalued. The underlying reasons are two-fold: First, for thousands of years, Chinese peasants have retained close links with their plots of land. Conscious of their rural roots, migrant workers rarely uproot themselves from their home villages although most villagers have invested little in agricultural work. Even if young peasants obtain jobs and marry in the city, they will have their new house built on the site of the old one in the countryside, and/or buy a commercial apartment in a small city, county, or town near their home village, they will hold the wedding ceremony in their native village, and usually also send back their pregnant wives to their native village for care that they seek from the older generation.

Secondly, migrants are denied the possibility of becoming urban citizens for reasons of policy. To acknowledge the special difficulties faced by labour migrants in China, it is necessary to understand its unique household registration (hukou) system, which was established in 1958. Under the hukou system, people were classified as either rural and urban residents and before the 1980s rural-urban migration was strictly prohibited. Even in recent decades with migration effectively encouraged, the type of household registration (rural or urban) can be changed only in exceptional circumstances. Therefore, the vast majority of rural Chinese is tied to their village by their agricultural hukou and the benefits attached to it, for example, the minimum living allowance (social assistance), cooperative medical insurance, and education for children.

Rural lineage, land rights, and the hukou system tie migrant workers to their homeland as a thread pulls a kite. And in a patrilocal culture, young married women have little choice but to go to their husbands' native village and live/neighbour with their in-laws while the husbands work away from home. As with Cai Ying, although they gain knowledge and capability to become independent wage-earners through their experience of being migrant workers, marriage embeds or entraps them back in a patriarchal system. Cai Ying reverted from an individual to a family-oriented housewife, and subsequently from independence to being husband-centered.

A similar fate would appear to await the younger women in Maple Village, albeit they are hoping for something different. Traditionally, young women got betrothed between the ages of about 20 and 22 and married at around 24. In marked distinction, all the unmarried women in Maple Village had left the Village by the age of 19 , some as early as 16 . Obtaining work was not their only goal as illustrated by unmarried 19-year-old Chen Yu:

I want to meet more people before I find my marriage partner. It would be impossible for me to go out to 
see the outside world after I'm 22 years old. Parents will find someone for me to marry in the Village or in neighboring villages.

When asked about her future plans, Chen Yu was uncertain about where the future would take her because she still had not find a marriage partner. She reflected:

I will wait and see. I prefer to live in the city if I can find someone there. But most likely I will be soon going back to the marriage partner's village wherever it is. All women will get married after all, then go home and let his family support me.

While as already noted, migration can lead to young women having a different world view, and the norm of patrilocality remains a dominant factor. A survey in 2019 of the status of Chinese women indicates that as many as $70 \%$ of peasant women still adopt patrilocal residence and only about a quarter living away from their husbands' villages (Liu, Liu, \& Jin, 2019). Until a fundamental change takes place in the three pillars of the rural household-patrilocal residence, patrilineal descent, and patriarchal authority-being married means that these women will once again be embedded in family power relations of domination and subordination and will thereafter be subject to the norms and constraints of patriarchal ideology. They drift away from the old family relations and become atomic individuals, only then to become re-embedded into a reconstruction of patriarchal family relations. While not a simple reproduction of the original system, it largely maintains the gender hierarchy and sexual role norms of the traditional family.

\section{Patriarchy and Women's Under-Representation in Village Decision-Making}

While young women 'left-behind' in Maple Village are both better educated and more world experienced than in the past, they were no more able to participate in Village governance and public affairs. In Maple Village, between 2006 and 2016, no women were engaged in the Village management committee and none of $28 \mathrm{mem}$ bers of the village Party branch were women in 2016. The Village head of Maple Village explained:

Young women are more capable than the older generations. But it is a rule for women to stay inside to look after the family and men work outside to deal with big issues. It also works in Village governance.

Other male members in the Village committee confirmed and amplified this traditional, discriminatory perspective:

Women usually don't care about village politics; rather, they are more interested in gossiping about more trivial things....Women are usually narrow- minded, they are born to be homemakers. (Personal communication, Chen, 2016)

Women are still incapable of managing the Village. An intelligent woman is at most a good adviser for her husband. But can you imagine that the whole Village is all led by a woman? I have never heard about it. (Personal communication, Wang, 2015)

However, these views were not in accord with the facts as revealed in an attitude survey conducted as part of the fieldwork. This indicated that $40 \%$ of young women in Maple Village, including five female Party members, were keen to be involved in Village governance, particularly in resource allocation decisions such as land rotation and dibao (minimum living standard allowance) management. However, in China's patriarchal society, unmarried young women are not considered to be family members or village members and consequently have no property rights or political rights. Married women, although considered as family and community members, often encounter practical constrains in political participation as explained by Peng, a Party member in her mid-30s who moved to Maple Village from Hunan:

I have lots of ideas of how to improve our Village. Some are good practices that I have experienced in my natal village. But it is unlikely for me to be elected as Village head by villagers. I have only lived in this Village for a few years. People know me as an outsider, especially as I come from a distant place and still cannot speak the local dialect....People would never let a woman with southern accent decide for them. I cannot even speak to the Village cadres about my ideas. I can imagine that if I go to talk to them, not only myself, but my husband and the whole family would be teased for it.

The political aspirations of women in Maple Village firmly held in check by patriarchal system of Village governance that, in 2016, meant that even the position of women's representative on Maple Village committee was taken by a man. Male Village cadres prioritized the masculine nature of Village governance and women were consequently excluded from Village decision-making. In 2016, even the Patrilocal institution further deprived women's social capital and it further prevented them from make allies in politics.

As such, Maple Village is not exceptional (e.g., Jacka, 2018; Jacka \& Sargeson, 2015; Yu \& Cui, 2019). According to the third national survey of women's status conducted in 2010 , women accounted for only $5.8 \%$ Village directors (including vice directors) and $5.4 \%$ of female Village Party secretaries (including vice secretaries; Song \& Zhen, 2013 , p. 286). While young women may have gained considerable experience of independent decision-making during migration, their autonomy is heavily constrained on their return to Village both within the family and es- 
pecially in political life. Denied the opportunity to exploit their experience and to build political and social capital, women are likely to remain left behind not just geographically in the Village, but in all spheres of social and political life (Luo \& Chui, 2019).

\section{Conclusion}

The research suggests that an important consequence of sustained large-scale migration has been an erosion of regional identity and the dissolution of a sense of local belonging for many young women who have migrated. While women acquire experience and knowledge as a consequence of migration that might be thought likely to empower them (Jacka, 2006; Jin, 2010; Seeberg \& Luo, 2017; Shen, 2016; Sun, 2016), their role in their patrilocal village, being excluded from active participation in village governance, regresses to that of 'the person inside my home.'

Through acknowledging migration as a short-term experience in women's life course, this article problematizes contemporary discourse on the dichotomy of migrant and left-behind women. While 'husbands work as migrant labors and wives left-behind' has become a new gendered division of labor, this should not be construed as meaning that women have been passively left behind as 'victims' as may have been true for first generation migrants. Rather, women themselves have been migrating in ever larger numbers and, with a focus on young women's life stories after temporarily or permanently returning to their home villages from migrant work, the article reveals that continuous large-scale migration has been an important structural force enabling change in rural families. As Shen (2016) has also demonstrated, large-scale migration has transformed the traditional patriarchal orders in Chinese rural society by increasing non-patrilocal residence. This research further shows that women's agency is conditioned by various forces playing in both enabling and constraining ways. Paying attention to the comprehensiveness of social, cultural, and geographic contexts also enables us better to understand women's status and gender practices. For migrant returnees, increasing numbers of cross-provincial marriages have broken local customs, while both men and women's exposure to more equal gender practice in urban settings have helped reconstruct gender relations within rural households. The implications of younger generations becoming the main bread earners for the extended family are particularly profound, weakening the intergenerational transmission of beliefs and values.

However, despite the active engagement of women in migration, gaining new life-skills during the process and the increasing freedom to choose life partners for themselves (Sun, 2019; Zhang, 2013), family power relations, and gender norms have only partially altered. The essential characteristics of the patriarchal institution, including the paternal lineage system and male dominance in decision-making, have remained largely unchallenged. When migrant women leave the city on pregnancy to live in the husband's village, they re-enter a world framed by patriarchy. The traditional convention that 'the man dominates outside and the woman dominates inside' and that the destiny of a woman is to be 'the person inside my home' continues to hold back women's progress.

\section{Acknowledgments}

This work was supported by the Projects of China 111 Program: the Overseas Expertise Introduction Center for South China Karst Ecoenvironment Discipline Innovation (No. D17016) and the National Key Research and Development Program of China in the 13th Five-Year Plan: Ecological Industry Model and Integrated Technology and Demonstration for the Rocky Desertification Control of the Karst Plateau Gorge (No. 2016YFC0502607).

\section{Conflict of Interests}

The authors declare no conflict of interests.

\section{References}

An, F., Broadbent, K., \& Yuan, F. (2018). Employment inequality among women migrant workers in China: Comparative analysis from the 2014 Guangdong migrant workers survey. Asian Pacific Journal of Human Resources, 56(4), 518-538.

$\mathrm{Au}$, L., \& Nan, S. (2007). Chinese women migrants and the social apartheid. Development, 50(3), 76-82.

Chen, F. (2004). The division of labor between generations of women in rural China. Social Science Research, 33(4), 557-580.

Chen, Q., \& He, J. (2015). Nongcun liushou funv shehui zhichi yanjiu zongshu [Research review of rural leftbehind women and their social support with a social work perspective]. Funv yanjiu luncong, 2(128), 106-112.

Chen, W. (2019). Mobile children: Research on generational-pass on and different life course of young migrants. Chinese Youth Studies, 276(2), 47-56.

Chinese Women and Children's Rights Coordination Group. (2007). Zhongguo nongcun funv quanyi zhuangkuang he weiquan xuqiu diaocha baogao [National rural Chinese women's rights and right protection research report]. Zhongguo fuyun, 2007(3), 5-11. Retrieved from http://mall.cnki.net/magazine/ Article/ZFYZ200703003.htm

Du, P. (2019). Xingbie bu xinren jiqi duoyanghua shengchan: Dagong qingnian xinren yu qinmi guanxi de hudong fenxi [Gender non-trust and diversified reproduction: Dynamic analysis of migrant youth trust and intimate relations]. Funv yanjiu luncong, 2, 30-43.

Jacka, T. (2006). Rural women in urban China: Gender, 
migration, and social change. New York, NY: M. E. Sharpe.

Jacka, T. (2008). Increasing women's participation in village government in China: Is it worth it? Critical Asian Studies, 40(4), 499-530.

Jacka, T. (2012). Migration, householding and the wellbeing of left-behind women in rural Ningxia. The China Journal, 67(1), 1-22.

Jacka, T. (2018). Translocal family reproduction and agrarian change in China: A new analytical framework. The Journal of Peasant Studies, 45(7), 1341-1359.

Jacka, T., \& Sargeson, S. (2015). Representing women in Chinese village self-government: A new perspective on gender, representation and democracy. Critical Asian Studies, 47(4), 477-494.

Jin, Y. (2009). Lisan Zhong de mihe: Nongcun liudong jiating yanjiu [Reunion after long separation: A study of migrant worker families]. Jiangsu shehui kexue, 2, 98-102.

Jin, Y. (2010). Liudong de fuquan: Liudong nongmin jiating de bianqian [Mobile patriarchy: Transitions of rural migrant families]. Zhongguo shehui kexue, 4, 151-159.

Judd, E. (1994). Gender and power in rural North China. Stanford, CA: Stanford University Press.

Li, X. (2016). Shoutu yu lixiang zhong de xingbie shiheng [Gender unbalance between left-behind and migrate]. Zhongnan Minzu Daxue Xuebao (Shehui kexue ban), 26(1), 17-19.

Li, S., Yang, X., Yue, Z., \& Jin, X. (2007). Nongmingong shehui zhichi wangluo de xianzhuang jiqi yingxiang yinsu yanjiu [Research on social support networks of migrant workers and their influencing factors]. Xi'an Jiaotong Daxue Xuebao (Shehui Kexueban), 27, 67-76.

Liu, L., Liu, H., \& Jin, X. (2019). Waichu wugong ruhe yingxiang nongcun liudong renkou de chuhun nianling? [How does migrant work impact on the first marriage age of rural migrants?]. Renkou yu jingji, 234(3), 36-51.

Liu, M., Lin, R., Zhang, Y., \& Li, C. (2019). Nongye zhuanyi renkou jiqi jiating chengzhenhua moshi tantao [Exploration on rural migrants and their family urbanization]. Jingji Yanjiu Daokan, 396(10), 41-42.

Liu, Y., Yin, Q., Huang, H., Lin, C., \& Zhang, Z. (2010). Liudong funv yu liudong nanxing de xinli jiankang yu shehui zhichi [Mental health and social support of female and male migrants]. Zhongguo Xinli Weisheng Zazhi, 24(8), 631-632.

Luo, M. S., \& Chui, E. W. T. (2019). Moving from rural to urban China: How urbanization affects women's housework. Sex Roles, 81(3/4), 127-139.

Murphy, R. (2002). How migrant labour is changing rural China. New York, NY: Cambridge University Press.

National Bureau of Statistics of the People's Republic of China. (2009). Nian mo quanguo nongmingong zongliang wei 22542 wan ren [Migrant workers population has reached 225.42 million by end of the year]. Gov.cn. Retrieved from http://www.gov.cn/ gzdt/2009-03/25/content_1268173.htm

National Bureau of Statistics of the People's Republic of China. (2016). 2015nian nongmingong jiance diaocha baogao [2015 survey report on migrant workers]. National Bureau of Statistics of the People's Republic of China. Retrieved from http://www.stats.gov.cn/tjsj/ zxfb/201604/t20160428_1349713.html

$\mathrm{Pu}, \mathrm{K} .$, \& Chen, X. (2018). Xingbie shiheng, jieceng jingzheng yu nongcun fanxiang nianqing nvxing jiating diwei de jueqi: Jiyu qiannan $Z$ cun de diaocha [Gender unbalance, social class competition and rising family status of returned young rural migrants: A survey of $Z$ village in south Guizhou]. Renkou yu fazhan, 24(5), 98-105, 130.

Sargeson, S. (2018). Gender and employment in rural China. Gender \& Development, 26(1), 212-213. https://doi.org/10.1080/13552074.2018.1435062

Seeberg, V., \& Luo, S. (2017). Young women rural migrant workers in China's west: Benefits of schooling? Frontiers of Education in China, 12(3), 332-366.

Shek, D. T. (2006). Chinese family research puzzles, progress, paradigms, and policy implications. Journal of Family Issues, 27(3), 275-284.

Shen, Y. (2016). Filial daughters? Agency and subjectivity of rural migrant women in Shanghai. The China Quarterly, 226, 519-537.

Smyth, J. D., Swendener, A., \& Kazyak, E. (2018). Women's work? The relationship between farmwork and gender self-perception. Rural Sociology, 83(3), 654-676.

Song, X., \& Zhen, G. (2013). An investigation of Chinese women's social status (Part 1). Beijing: Chinese Women Press.

Sun, J. (2016). Her voice in the making: ICTs and the empowerment of migrant women in Pearl River Delta, China. Asian Journal of Women's Studies, 22(4), 507-516.

Sun, W. (2019). Inequality in mobility: The pursuit of conjugal intimacy for China's rural migrant women in industrial Shenzhen. Journal of Intercultural Studies, 40(3), 302-317.

Xiang, J. (2015). Gendered pathways to hukou status mobility in China. Chinese Journal of Sociology, 1(2), 231-253.

Yan, Y. (2003). Private life under socialism: Love, intimacy, and family change in a Chinese village, 1949-1999. Stanford, CA: Stanford University Press.

Yu, H., \& Cui, L. (2019). China's e-commerce: Empowering rural women? The China Quarterly, 238, 418-437.

Zeng, J., Pang, X., Zhang, L., Medina, A., \& Rozelle, S. (2014). Gender inequality in education in China: A meta-regression analysis. Contemporary Economic Policy, 32(2), 474-491.

Zhang, N. (2006). Social networks and women's ruralurban migration in contemporary China. Capital and Society, 39(2), 112-113.

Zhang, N. (2013). Rural women migrant returnees in 
contemporary China. The Journal of Peasant Studies, 40(1), 171-188.

Zhang, N. (2014). Performing identities: Women in ruralurban migration in contemporary China. Geoforum,
$54,17-27$.

Zhu, H. (2018). Nongcun liushou funv wenti yanjiu shuping [Research review about rural left-behind women]. Funv yanjiu luncong, 1, 92-95.

\section{About the Authors}

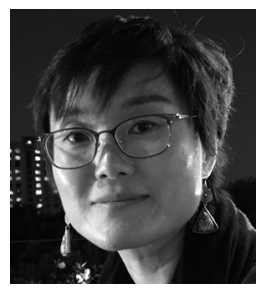

Lichao Yang is an Associate Professor at the School of Social Development and Public Policy, Beijing Normal University. She is a proactive Lecturer and Researcher with learning and academic experiences in four countries. She held nine research grants, including seven international collaborative research projects. She has published two books, one single authored monograph on development, gender and participation the other an edited volume on contemporary development of China, and 24 academic articles, reports, and book chapters.

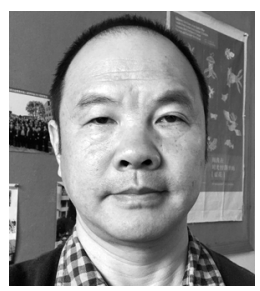

Xiaodong Ren is a Professor at School of Karst Science, and Professor of National Engineering and Technological Research Center of Karst Rocky Desertification Prevention and Control, Guizhou Normal University. His main research fields are community development, gender, community-based environmental protection and development project management with hosting more than 90 international and domestic cooperative research projects, he has published two books and more than 80 articles. 